\title{
TEORI-TEORI TRANSORIENTASIONAL DALAM PSIKOLOGI SOSIAL
}

\author{
Juneman \\ Jurusan Psikologi, Fakultas Humaniora, BINUS University \\ Jl. Kemanggisan Ilir III No. 45, Kemanggisan/Palmerah, Jakarta Barat 11480 \\ juneman@binus.ac.id
}

\begin{abstract}
The author discusses the recognition of social judgment theory, descriptive model of social response, and role theory as transorientational social psychological theories, criticism in this field as well as their application in everyday's life.
\end{abstract}

Keywords: trans orientational approaches, social judgment, social response, role theory, social psychology

\begin{abstract}
ABSTRAK
Penulis mengulas pengenalan terhadap teori penilaian sosial, model deskriptif tentang respons sosial, dan teori peran sebagai teori-teori psikologi sosial transorientasional, evaluasi/kritik dalam lapangan ini, dan aplikasinya dalam kehidupan sehari-hari.
\end{abstract}

Kata kunci: pendekatan transorientasional, penilaian sosial, respons sosial, teori peran, psikologi sosial 


\section{PENDAHULUAN}

Shaw \& Costanzo (1970) mengemukakan bahwa terdapat dua pendekatan teoretis dalam psikologi sosial, yakni pendekatan-pendekatan umum atau tradisional (general/traditional approaches) dan pendekatan-pendekatan transorientasional (transorientational approaches). Pendekatan-pendekatan atau orientasi umum (misalnya, orientasi psikoanalitis, orientasi kognitif) memberikan basis atau dasar bagi berbagai teori psikologi sosial yang dikembangkan dalam atau yang merupakan representasi dari orientasi tersebut (misalnya, teori FIRO, teori P-O-X). Di samping teoriteori yang berlandaskan orientasi umum, terdapat pula teori-teori psikologi sosial yang jelas-jelas bersifat eklektis atau pun unik, dalam arti bahwa teori-teori ini tidak bergantung pada salah satu orientasi umum, melainkan teori-teori ini menggunakan prinsip-prinsip yang diturunkan dari satu atau lebih pendekatan atau orientasi umum. Nama pendekatan yang memayungi teori-teori ini adalah pendekatan transorientasional, dan teori-teorinya disebut teori-teori transorientasional.

Merujuk Shaw \& Costanzo (1970), secara operasional sebuah teori disebut bersifat transorientasional apabila, antara lain, diturunkan dari dua atau lebih teori yang termasuk dalam golongan orientasi umum. Misalnya, teori Penyimpulan Korespondensi yang dikembangkan oleh Jones \& Davis (dalam Shaw \& Constanzo, 1970), berakarkan teori Heider-khususnya analisis Heider mengenai proses atribusi (orientasi lapangan) dan teori kognitif-yang membicarakan elemen-elemen kognisi seperti "intensi" dan "penyimpulan/inferensi" (orientasi kognitif). Di samping itu, teori transorientasional juga berarti bahwa teori tersebut menggabungkan sudut pandang disiplin ilmu lain. Misalnya, teori penilaian sosial (social judgment theory, SJT) memanfaatkan karya-karya dalam psikologi (khususnya psikologi penilaian, psikologi persepsi, psikologi belajar, dan psikologi ingatan) dan antropologi serta sosiologi (Shaw \& Costanzo, 1970).

Dalam pengertian "transorientasional" yang terakhir tersebut di atas, terdapat tiga hal yang patut dicatat. Pertama, bahwa dalam pengertian ini, psikologi sosial sendiri sesungguhnya merupakan sebuah disiplin ilmu transorientasional. Entah psikologi sosial yang berorientasi sosial (sociological social psychology, SSP) atau yang berorientasi individual (psychological social psychology, PSP), keduanya sama-sama merupakan bidang peririsan dari akar-akarnya dalam disiplin psikologi dan sosiologi, serta menggunakan unit analisis individu dan kelompok dalam penelitiannya (Barenbaum, 2000; “Social Psychology/ Introduction”, 2009).

Kedua, dewasa ini, teori-teori psikologi sosial semakin memiliki warna transorientasional. Contohnya adalah teori Representasi Sosial (social representations theory, SRT)—yang merupakan golongan SSP. Menurut Alaya (2009), teori yang digagas oleh Serge Moscovici (1961) ini berakar pada sedikitnya empat orientasi teoretis, yakni orientasi etnografis (Jodelet), orientasi yang menggunakan model struktural sosiologis Doise, dkk.), orientasi struktural (Abric), dan orientasi dialogis (Markova). Ketiga, urgensi pendekatan eklektis dalam psikologi muncul dari posmodernisme, sebagai sebuah posisi teoretis, yang dituntut untuk memberikan disputasi/perdebatan terhadap kebenaran dan validitas dari sejumlah metodologi dan teori ilmiah tradisional (Kvale dalam Giles, 2003).

Dalam tulisan ini, teori-teori transorientasional yang akan dibahas adalah teori penilaian sosial (social judgment theory), Model Deskriptif tentang respons sosial (descriptive model of social response), serta teori peran (role theory). 


\section{PEMBAHASAN}

\section{Teori Penilaian Sosial}

Sebagaimana disebutkan di atas, Teori penilaian sosial (SJT, social judgment theory) menggunakan sudut pandang psikologi, antropologi serta sosiologi (Shaw \& Costanzo, 1970). Menurut Littlejohn (2002), teori ini berakar dari penelitian psikofisik, dalam hal mana orang diuji kemampuannya untuk menilai stimuli fisik seperti berat benda atau kecerahan suatu cahaya. Dengan menggunakan penelitian ini, Muzafer Serif secara analogis menyelidiki cara-cara individu menilai pesan-pesan. Sherif mempelajari bahwa banyak prinsip-prinsip psikofisik berlaku pula bagi penilaian sosial.

SJT utamanya mempelajari proses-proses psikologis yang mendasari ekspresi sikap dan perubahan sikap melalui komunikasi (Shaw \& Costanzo, 1970: 295). Menurut Sherif (1963), perubahan sikap pribadi utamanya terjadi karena interaksi tiga faktor: (1) sikap awal/asli audiens, (2) pesan-pesan (atau opini orang lain), (3) kredibilitas pesan. Teori penilaian sosial menyatakan bahwa dalam sebuah momen persepsi, orang membandingkan pesan-pesan dengan sikap atau sudut pandangnya pada saat itu. Opini-opini individual tidak dapat secara tepat direpresentasikan sebagai titik-titik di sepanjang sebuah kontinum karena harus dipertimbangkan pula derajat toleransi di sekitar posisi-posisi opini tersebut (adanya jangkar/anchors, dan titik-titik rujukan).

Guna memahami lebih lanjut pernyataan di atas, lebih jelasnya, berikut ini diuraikan lima prinsip SJT (Sherif, Sherif, \& Nabergall, 1965).

Prinsip pertama: orang memiliki kategori-kategori penilaian (judgment) yang digunakan untuk mengevaluasi posisi-posisi persuasif. Contoh: dalam topik "Apakah kita seyogianya meningkatkan gaji guru?” posisi-posisi persuasif itu dapat memiliki rentang A sampai dengan I, sebagai berikut:
A. It is absolutely essential from all considerations that teachers' pay should be increased.
B. It almost certain from many angles that teachers' pay should be increased
C. It is highly probable that things would be better if teachers' pay was increased.
$D$. It is possible that it would be better if teachers' pay was increased.
E. It is difficult to say whether teachers' pay should be increased.
$F$. It is possible that it would be better if teachers' pay was not increased.
G. It is highly probable that teachers' pay should not be increased.
$H$. It is almost certain from most angles that teachers' pay should not be increased.
I. It is absolutely essential from all consideration that teacher's pay not be increased.

Tiap-tiap ekspresi sikap ini (dari posisi pro- sampai dengan anti-) dapat dikategorikan kedalam tiga zona: (1) garis lintang penerimaan (zona dari posisi-posisi yang diterima); (2) garis lintang nonkomitmen (zona dari posisi-posisi yang tidak diterima, tidak pula ditolak); dan (3) garis lintang penolakan (zona dari posisi-posisi yang ditolak), seperti pada Gambar 1.

Bagi kebanyakan guru, dua atau tiga pernyataan pertama (A sampai C) mungkin masuk dalam zona garis lintang penerimaan. Dalam zona ini terdapat satu posisi khusus yang disebut jangkar (anchor), dalam hal seseorang menganggapnya sebagai posisi yang paling dapat diterima. Dalam contoh di atas, posisi tersebut dapat saja berupa posisi ekstrim (absolute essential) atau posisi yang lebih lunak (highly probable). Sementara itu, ada guru-guru yang tidak menerima sejumlah posisi, tidak pula menolaknya. Guru-guru itu berada dalam zona garis lintang non-komitmen, dalam hal mana mereka tidak memiliki pendapat (have no real opinion). Dalam contoh di atas, posisi tersebut adalah 
posisi tengah (difficult to say). Pernyataan-pernyataan yang ada di sekitarnya (pernyataan D dan F) mungkin juga masuk dalam garis lintang ini, yang dianggap netral. Kebanyakan guru mungkin tidak ragu-ragu lagi menempatkan pernyataan-pernyataan "anti-“ (G sampai I) dalam garis lintang penolakan.

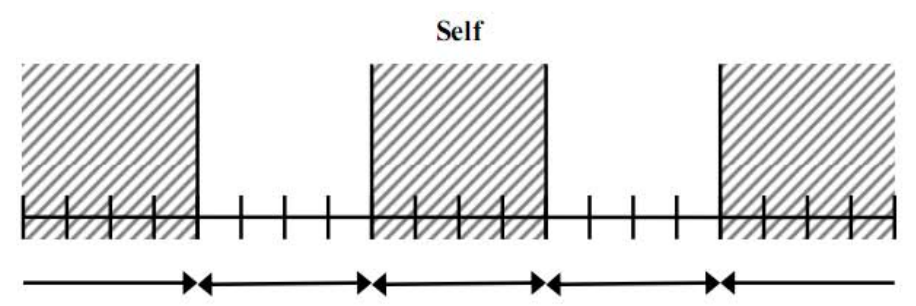

( reiection ) ( no comment ) ( accentance ) ( no comment ) (reiection )

Gambar 1 Lintang penolakan, lintang non-komitmen, dan lintang penerimaan

Sumber: Sherif, 1963

Prinsip kedua: ketika orang menerima informasi persuasif, ia menempatkan informasi itu dalam kategori penilaiannya. Implikasi dari prinsip ini adalah bahwa penilaian (judgment) merupakan hal yang krusial bagi persuasi. Menurut SJT, penilaian berlangsung secara sangat cepat. Orang tidak secara pasif menerima informasi, dan kemudian membuat penilaian; melainkan, orang membuat penilaian seketika (cukup otomatis) sewaktu ia menerima informasi. Penilaian dalam lintang penolakan membuat pengaruh persuasif menjadi sangat sulit. Penilaian dalam lintang non-komitmen dan penerimaan memberikan peluang bagi perubahan sikap. Dalam kondisi semua hal konstan (ceteris paribus), orang yang memiliki lintang penerimaan yang lebih besar lebih mudah dipengaruhi daripada orang yang memiliki lintang penolakan yang lebih besar. Makin terlibat ego kita dalam sebuah persoalan, lintang penolakan semakin besar dan lintang penerimaan dan non-komitmen semakin kecil.

Prinsip ketiga: Tingkat keterlibatan ego seseorang memengaruhi ukuran lintang. Keterlibatan ego merupakan representasi seberapa penting suatu isu/persoalan bagi identitas diri seseorang. Topik yang bersifat ego-involving merupakan topik yang mendefinisikan siapa diri serta menunjuk pada aspek-aspek kritis diri seseorang. Misalnya, kualitas kehidupan anak-anak kita mungkin merupakan sebuah persoalan kritis. Kita menginginkan anak-anak kita aman, bahagia, dan produktif. Hal apapun yang memengaruhinya akan membangkitkan minat vital kita (ego-involving) serta mempengaruhi semakin besar/kecilnya lintang penolakan/penerimaan kita.

Prinsip keempat: Orang cenderung mendistorsi informasi yang datang dengan cara menyesuaikannya dengan kategori penilaiannya, bergantung pada posisi jangkar-nya. Apabila sebuah informasi persuasif jatuh dalam lintang penerimaan dan dekat dengan posisi jangkar, maka orang akan melakukan asimilasi posisi baru tersebut. Orang akan menarik posisi baru itu lebih dekat ke dirinya dan membuatnya bahkan nampak lebih bisa diterima daripada yang sesungguhnya. Sebaliknya, apabila informasi persuasif jatuh di luar lintang penerimaan, orang akan melakukan kontras terhadap posisi baru tersebut. Orang akan mendorong posisi baru itu lebih jauh dari dirinya dan membuatnya bahkan nampak lebih buruk daripada yang sesungguhnya (gejala polarisasi).

Asimilasi maupun kontras mendistorsi posisi sesungguhnya dari informasi baru. Apabila distorsi seperti ini terjadi, informasi baru tidak akan memiliki efek persuasif. Ada dua penyebabnya. Pertama, apabila kita melakukan kontras, kita mendorong informasi baru keluar dari lintang penerimaan dan mungkin mendorongnya hingga jatuh dalam lintang penolakan. Dalam hal ini, tidak terjadi persuasi. Kedua, apabila kita melakukan asimilasi, kita menarik informasi baru ke diri kita dan membuatnya seolah-olah posisi itu sudah merupakan posisi yang kita terima. Tidak terjadi persuasi juga. 
Prinsip kelima: Diskrepansi yang kecil sampai dengan moderat antar posisi-posisi jangkar kita akan menyebabkan perubahan sikap, apabila salah satu posisi jangkar kita didukung. Diskrepansi yang besar tidak akan menyebabkan perubahan sikap. Menurut SJT, persuasi merupakan proses yang sangat sulit karena tiga alasan. Pertama, persuasi tidak akan terjadi apabila sebuah informasi baru jatuh dalam lintang penolakan. Kedua, apabila seseorang memiliki keterlibatan ego yang tinggi dalam suatu persoalan, maka lintang penolakan akan lebih besar dari biasanya, dan persuasi menjadi lebih sulit (Gambar 2). Artinya, orang menolak setiap informasi yang tidak sinkron dengan sikapnya. Ketiga, orang cenderung mendistorsi informasi baru melalui asimilasi dan kontras yang melemahkan potensi persuasif dari informasi baru. Jadi, tidak terdapat banyak ruang yang tertinggal untuk terjadinya perubahan.

Menurut SJT, persuasi akan terjadi apabila ketiga kondisi ini terpenuhi: (1) informasi baru (posisi baru yang ditawarkan oleh orang lain) harus jatuh dalam lintang penerimaan (misalnya, pesan berasal dari orang yang kredibel, atau pesan bersifat ambigu namun secara umum konsisten dengan sikap awal seseorang); (2) informasi baru harus berbeda dari posisi jangkar; dan (3) informasi baru tersebut tidak dapat diasimilasikan atau pun dikontraskan. Hal ini dapat dianalogikan dengan obat.

Apabila seseorang menerima resep obat, di dalamnya dijelaskan dosis (berapa banyak) dan frekuensi (berapa sering) minum obat yang dihimbau. Orang akan memperoleh manfaat maksimum apabila orang minum dosis yang tepat pada waktu yang tepat. Apabila orang minum terlalu sedikit atau terlalu banyak, orang tidak akan berubah menjadi sembuh. Demikian pula dengan persuasi. Sepanjang terdapat resep jumlah kesenjangan (diskrepansi) antara posisi jangkar dan posisi baru, persuasi dapat terjadi. Apabila diskrepansi terlalu kecil atau terlalu besar, persuasi tidak akan terjadi atau bahkan terjadi efek bumerang.

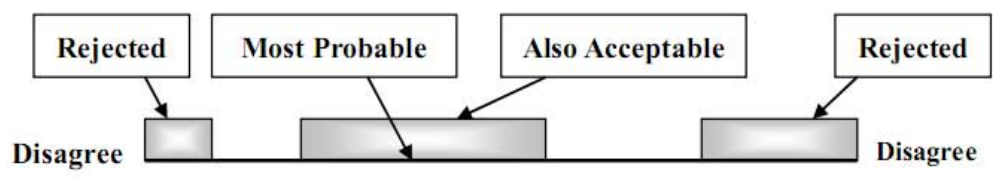

A. assimilation-contrast area for an individual less-involved

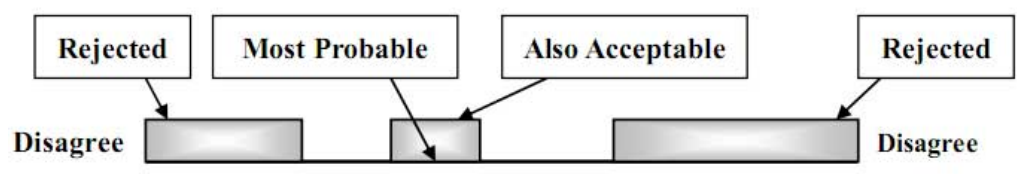

B. assimilation-contrast area for an individual highly-involved

Gambar 2 Efek asimilasi-kontras, keterlibatan ego, dan peluang perubahan sikap

Sumber: Kotler dalam Yang \& Yang, 2007)

\section{Model Deskriptif tentang Respons Sosial}

Teori yang disebut juga sebagai model intan tentang perilaku konformitas (diamond model of conformity behaviour) ini dikembangkan oleh Willis (dalam Shaw \& Costanzo, 1970) dan berkaitan dengan respons-respons terhadap pengaruh sosial.

Willis lebih suka menyebut teorinya sebagai model, karena menurutnya—sesuai dengan yang dikembangkannya—model itu deskriptif (menggambarkan suatu keadaan), tidak eksplanatif (menjelaskan hubungan sebab-akibat). Di samping itu, model hanya memperkirakan kemungkinankemungkinan yang nyata (possibilities) yang benar-benar dapat terjadi, sedangkan teori membahas 
juga kebolehjadian (probability) yang secara teoretis dapat terjadi, tetapi dalam kenyataannya belum tentu akan terjadi (Sarwono, 2002). Meskipun demikian, model dari Willis memenuhi definisi minimal teori dari Shaw \& Costanzo (1970), karena analisis Willis tidak hanya menggambarkan jenis-jenis respons yang mungkin terjadi, tetapi juga mengidentifikasikan kondisi-kondisi (syarat-syarat) dalam mana respons-respons yang beragam terjadi serta relasi-relasi antar respons-respons itu, di samping juga mengandung serangkaian hipotesis menyangkut konsekuensi dari modus-modus respons yang beragam (Shaw \& Costanzo, 1970).

Model intan Willis diilustrasikan dalam Gambar 3. Willis menjelaskan bahwa terdapat empat modus (cara) respons sosial (Sarwono, 2002), yakni konformitas, independensi, anti-konformitas, dan variabilitas. Modus respons tertentu dapat diramalkan dengan memperhatikan empat faktor, yakni kompetensi individu, kompetensi kelompok (mayoritas) atau partner, sikap yang dianut individu, dan struktur ganjaran.

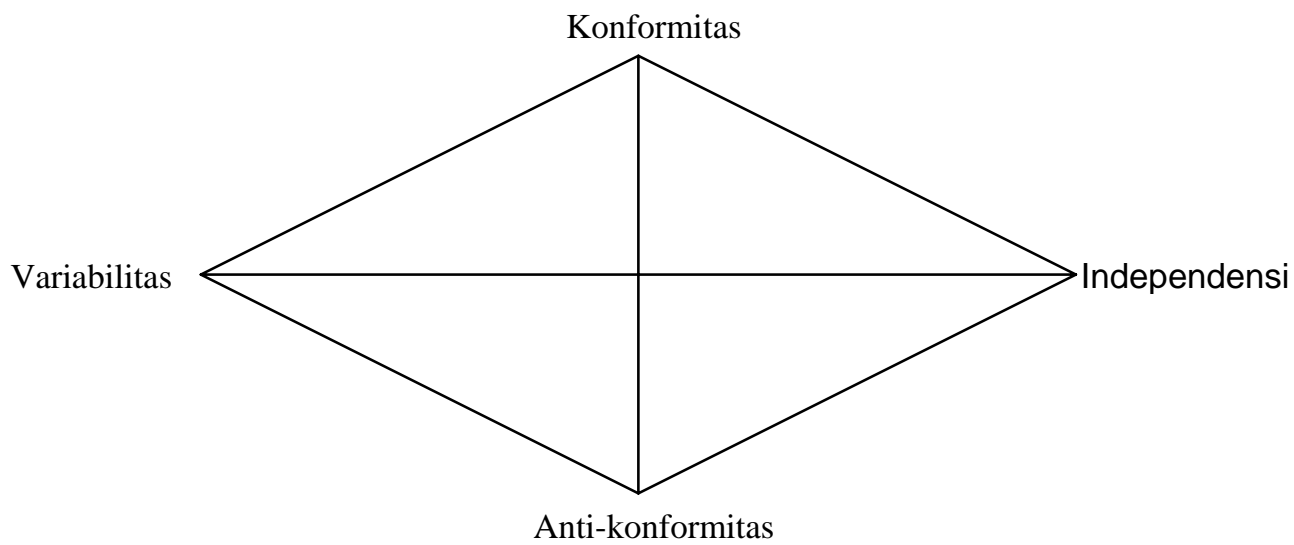

Gambar 3 Model intan tentang respons-respons sosial Sumber: Willis dalam Shaw \& Costanzo (1970)

Konformitas adalah perilaku konformitas yang murni adalah usaha terus-menerus dari individu untuk selalu selaras (kongruen) dengan norma-norma yang diharapkan oleh kelompok. Apabila persepsi individu tentang norma-norma kelompok (standar sosial) berubah, maka ia akan mengubah (movement) pula tingkah lakunya. Perilaku konformitas diperkirakan akan timbul secara maksimal jika: (1) kompetensi kelompok atau rekan relatif lebih tinggi dari kompetensi individu; (2) individu menganut sikap fleksibel; dan (3) ganjaran lebih besar jika respons selaras dengan norma kelompok.

Independensi atau ketidaktergantungan adalah perilaku independen yang murni adalah perilaku yang memberi nilai nol pada norma-norma yang berlaku. Ini bukannya berarti bahwa individu sama sekali mengabaikan norma-norma. Individu tetap tahu bahwa ada norma-norma (standar sosial), namun ia tidak membiarkan respons-responsnya dipengaruhi oleh standar sosial tersebut. Perilaku independen akan muncul pada tingkat maksimum jika: (1) individu lebih kompeten; (2) sikapnya konsisten; dan (3) ganjaran lebih besar jika ia membuat respons yang benar.

Anti-konformitas adalah perilaku anti-konformitas murni adalah perilaku yang merupakan respons terhadap norma tersebut, akan tetapi yang arahnya justru berlawanan dengan norma. Dengan perkataan lain, seorang anti-konformis justru memilih perilaku-perilaku yang menurut standar sosial dinilai tidak benar. Perilaku anti-konformitas akan maksimal jika: (1) kelompok tidak kompeten; (2) sikap individu fleksibel; dan (3) ganjaran lebih besar jika individu membuat respons yang benar. 
Variabilitas atau keragaman sebagai variabilitas yang murni yaitu perilaku yang berubahubah tidak membantu dan tidak berkaitan dengan norma-norma yang dipersepsikan individu. Jadi, gerak (movement) di sini tidak ditentukan oleh standar sosial dan standar sosial tidak diberi nilai apapun oleh individu. Orang yang respons sosialnya tergolong variabilitas murni dapat disebut juga self anti-conformity (tidak konform terhadap diri sendiri), karena perilakunya sama sekali tidak sesuai dengan perilaku-awalnya sendiri. Perilaku variabilitas jarang terjadi dan berasosiasi dengan harga diri yang sangat rendah.

Dalam kenyataan sehari-hari, tidak pernah ada respons yang murni. Respons-respons sosial selalu merupakan campuran dari keempat modus dan hal ini dapat digambarkan posisinya pada model tersebut di atas (Gambar 3). Modus respons dan kompetensi individu, menurut Willis, akan memengaruhi persepsi orang lain terhadap individu tersebut dan pada gilirannya akan memengaruhi interaksi sosial antar-individu. Misalnya, anti-konformis yang kompeten akan lebih menyenangkan daripada yang tidak kompeten; konformis yang tidak kompeten akan lebih menyenangkan daripada yang kompeten; dan individu yang kompetensi dan sekaligus independen akan paling menyenangkan apabila ia bekerjasama dengan kelompok yang kompeten pula.

Pengembangan paling mutakhir dari model respons sosial adalah Model Konteks Respons Sosial (social response context model, SRCM) (MacDonald, Nail, \& Levy, 2004). Model ini pada dasarnya hendak mengidentifikasikan serta mendiskriminasikan kompleks-kompleks respons unik seseorang terhadap pengaruh sosial. Penilaian terhadap dimensi-dimensi SRCM dapat dilakukan dengan menanyakan empat pertanyaan, sebagai nampak pada Tabel 1.

Tabel 1 Dimensi-dimensi SRCM

\begin{tabular}{|c|c|c|}
\hline No. & Dimensi & Pertanyaan untuk asesmen \\
\hline 1. & $\begin{array}{l}\text { Pra-paparan, kesetujuan/ketidaksetujuan } \\
\text { publik (Preexposure, public } \\
\text { agreement/disagreement, PRE-PUB A/D) }\end{array}$ & $\begin{array}{l}\text { Apakah posisi publik seseorang secara relatif terhadap } \\
\text { sumber pengaruh final sebelum paparan terhadap } \\
\text { pengaruh berlangsung? (What is a person's public } \\
\text { position relative to an eventual influence source before } \\
\text { exposure to influence?). }\end{array}$ \\
\hline 2. & $\begin{array}{l}\text { Pra-paparan, kesetujuan/ketidaksetujuan } \\
\text { privat (Preexposure, private } \\
\text { agreement/disagreement, PRE-PRI A/D) }\end{array}$ & $\begin{array}{l}\text { Apakah posisi privat orang tersebut sebelum pengaruh } \\
\text { berlangsung? (What is that person's private position } \\
\text { before influence?). }\end{array}$ \\
\hline 3. & $\begin{array}{l}\text { Pasca-paparan, } \\
\text { kesetujuan/ketidaksetujuan privat } \\
\text { (Postexposure, private } \\
\text { agreement/disagreement, POST-PRI } \\
\text { A/D) }\end{array}$ & $\begin{array}{l}\text { Apakah respons privat orang tersebut setelah pengaruh } \\
\text { terjadi? (What is that person's private respons after } \\
\text { influence?). }\end{array}$ \\
\hline 4. & $\begin{array}{l}\text { Pasca-paparan, } \\
\text { kesetujuan/ketidaksetujuan publik } \\
\text { (Postexposure, public } \\
\text { agreement/disagreement, POST-PUB } \\
\text { A/D) }\end{array}$ & $\begin{array}{l}\text { Apakah respons privat orang tersebut setelah pengaruh } \\
\text { terjadi? (What is that person's private response after } \\
\text { influence?). }\end{array}$ \\
\hline
\end{tabular}

Analisis kombinasional yang dilakukan terhadap keempat dimensi tersebut menghasilkan 16 (enam belas) respons, sebagaimana nampak pada Gambar 4. Model/teori ini bersifat transorientasional karena analisisnya menggabungkan dan menjangkau konstruk-konstruk, yaitu: psikologi politik; budaya dan agresi; persuasi-diri; norma kelompok; prasangka; manajemen kesan; psikoterapi; pengabaian majemuk (pluralistic ignorance); intervensi/nonintervensi bystander; kebijakan publik; hubungan intim; dan sikap implisit. Dalam artikel ini, hanya beberapa respon sosial yang dibahas. 


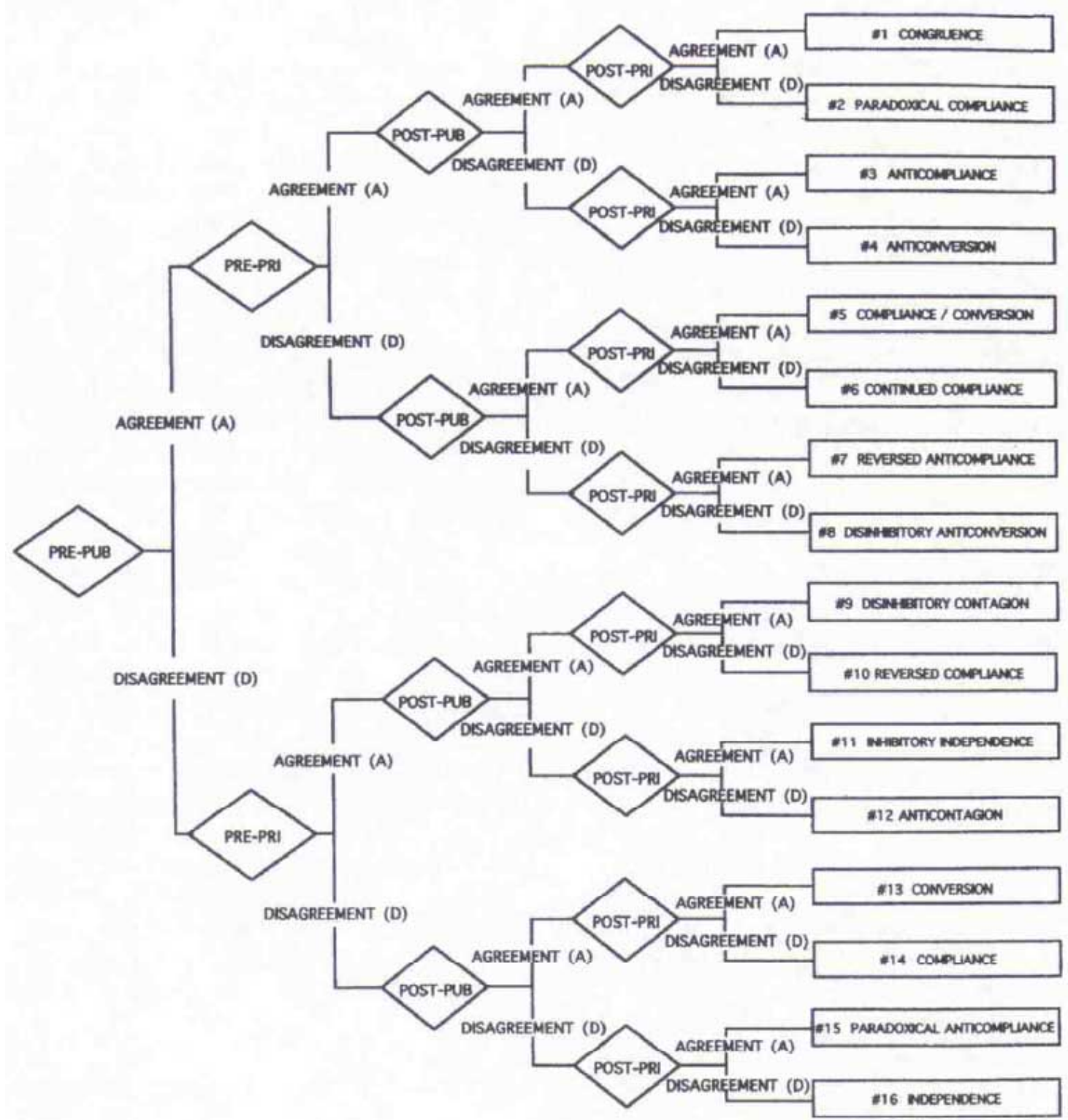

Gambar 4 Model konteks respons sosial Sumber: MacDonald, Nail, \& Levy, 2004

Respons sosial \#2, Paradoxical compliance (kepatuhan paradoksal): Setelah diberi pengaruh sosial, subjek tetap terus menyetujui sumber pengaruh sosial tersebut secara publik, namun secara pribadi/privat bergeser ke posisi tidak setuju.

Respons sosial \#3, Anticompliance dan \#4 Antikonversi: Anticompliance dicirikan oleh ketidakpatuhan/ketidaksetujuan yang berhubungan dengan konsen penyajian diri (self-presentational) atau manajemen kesan (impression management); sedangkan anticonversion dicirikan oleh ketidakpatuhan karena dorongan motivasional (motivational drives).

Respons sosial \#8, Disinhibitory anticonversion: Individu mulanya setuju dengan sumber pengaruh sosial secara publik (namun tidak secara privat), tetapi kemudian subjek bergerak ke posisi tidak setuju secara publik; jadi hasil akhirnya adalah ketidaksetujuan (disagreement) terhadap sumber pengaruh sosial baik secara publik maupun secara privat. 
Respons sosial \#11, Inhibitory Independence (Noncontagion): Sebelum terpapar oleh pengaruh sosial, subjek berada dalam konflik mendekat-menjauh, dan secara privat ingin melibatkan diri dalam perilaku menurut pengaruh sosial, namun secara publik tidak melakukannya. Yang terjadi selanjutnya bukanlah resolusi/penyelesaian konflik tersebut, tetapi subjek tetap terkekang dalam konflik tersebut namun tidak terpengaruh (uninfluenced, independent of) oleh perilaku model yang menjadi sumber pengaruh sosial.

Respons sosial \#12, Anticontagion: Sama dengan inhibitory independence, namun respons privat subjek berubah dari kesetujuan pra-paparan pengaruh (preexposure agreement) menjadi ketidaksetujuan pasca-paparan (postexposure disagreement). Jadi, tidak hanya bahwa subjek tidak secara positif terpengaruh oleh model, namun subjek juga bergerak ke arah berlawanan terhadap perilaku model berkenaan dengan respons privatnya (anticontagion).

Respons sosial \#15, Paradoxical anticompliance (antikepatuhan paradoksal): Setelah diberi pengaruh sosial, subjek menunjukkan ketidaksetujuannya secara publik terhadap sumber pengaruh sosial, namun secara privat menggantinya ke posisi setuju.

Jelas bahwa model respons sosial SRCM dari MacDonald, Nail, dan Levy (2004) ini jauh lebih elaboratif dan memadai dibandingkan model sebelumnya dari Willis. Model Willis hanya memuat empat tipe respons, yakni konformitas, independensi, anti-konformitas, dan variabilitas; sedangkan model MacDonald, Nail, dan Levy mampu mengenali dan membedakan enam belas tipe respons sosial dalam satu model tunggal.

\section{Teori Peran}

Konsep peran berasal dari gagasan peran yang dimainkan aktor dalam sebuah sajian teatrikal. Menurut Shaw \& Costanzo (1970), teori peran merupakan perpaduan berbagai teori, orientasi, maupun disiplin ilmu (psikologi, sosiologi, antropologi). Lynch (2007) mengungkapkan bahwa teori peran berakar dari perspektif fungsionalis (antropologis) dan perspektif interaksionis (sosiologis) dalam memahami masyarakat.

Dalam perspektif fungsionalis (antropologis), sebuah peran dipandang sebagai sekumpulan harapan yang ditempatkan masyarakat pada individu. Harapan peran (role expectations) terdiri dari hak serta hak istimewa, tugas-tugas dan kewajiban-kewajiban, dari setiap orang mengenai posisi sosialnya dalam relasinya dengan orang-orang lain yang memiliki posisi-posisi lain dalam struktur sosial. Dengan demikian, peran menciptakan pola-pola teratur mengenai perilaku serta mengukur keteramalan (predictability), yang tidak hanya memungkinkan individu untuk berfungsi secara efektif (karena mereka mengetahui apa yang diharapkan orang lain terhadap diri mereka), tetapi juga memungkinkan teoris-teoris sosial untuk membuat generalisasi mengenai masyarakat. Oleh karena definisi fungsionalis tentang peran menekankan harapan-harapan normatif dan ukuran pola-pola perilaku yang ditentukan oleh aturan-aturan dan konsensus sosial, maka perspektif ini memiliki kesulitan berkenaan dengan variabilitas multiplisitas peran (peran ganda), atau dengan perkataan lain, perspektif ini tidak mencakup konsep-konsep konflik peran, ketegangan peran (role strain), atau ambiguitas peran.

Menurut para teoris fungsionalis, peran-peran diciptakan oleh masyarakat sebagai sebuah keseluruhan dan bersifat lebih-kurang disetujui secara universal. Jembatan konseptual antara struktur sosial dan perilaku peran individual adalah konsep harapan (expectations). Untuk setiap unjuk peran, individu memiliki serangkaian harapan mengenai rentang keterlibatan yang tepat. Sebagai contoh, seorang dokter diharapkan berpakaian secara cukup konservatif, menanyakan serangkaian pertanyaan pribadi mengenai kesehatan seseorang, menyentuh orang dengan kemungkinan cara yang secara normal sehari-hari dilarang, menulis resep, serta menunjukkan konsen yang lebih besar (dibandingkan 
dengan tukang listrik atau penjaga toko) terhadap kesejahteraan pribadi kliennya. Peran dokter menentukan perilaku-perilaku yang diharapkan yang melekat pada posisi ini.

Harapan-harapan peran bervariasi sepanjang sejumlah kontinum, mencakup: (1) keumuman dan kekhususan (generalitas dan spesifisitas); (2) ruang lingkup dan ekstensivitas; serta (3) kejelasan dan ketidakpastian. Dalam kontinum keumuman, kita dapat melihat bahwa pada salah satu ujung dari kontinum ini, harapan peran menentukan secara persis perilaku yang diharapkan; sedangkan pada ujung yang lain, hanya terdapat garis-garis besar yang luas, yang memberikan pelaku peran pilihanpilihan mengenai perilaku-perilaku yang dapat diterima. Dalam kontinum ruang lingkup, sejumlah harapan tertentu membatasi ruang lingkup perilaku peran, dan memiliki relevansi terhadap ranah kehidupan seseorang yang sempit; sedangkan harapan-harapan yang lain (misalnya, yang berkaitan dengan usia) adalah yang berlaku terhadap bagian-bagian besar dari pengalaman sehari-hari.

Tingkat kesepakatan (konsensus) antar orang yang berkenaan dengan kinerja peran (role performance) juga merupakan salah satu aspek penting dari harapan peran, karena hal ini berkaitan dengan posisi sosial yang bersifat formal dan informal. Oleh karena aktor-aktor sosial cenderung untuk konform terhadap harapan-harapan peran, kejelasan dan konsensus menentukan tingkat sejauh mana sebuah unjuk peran dilihat sebagai meyakinkan, tepat/benar atau sesuai dengan konteks-konteks yang berbeda (sifatnya normatif dan evaluatif). Sebagai contoh, orang yang menjalani peran profesor universitas diharapkan untuk terlibat dalam tindakan-tindakan tertentu dalam waktu-waktu tertentu. Harapan-harapan ini bersifat timbal balik terhadap peran-peran komplementernya, yakni mahasiswa S1, asisten penelitian, atau dekan.

Definisi-definisi fungsional tentang peran secara jelas mengakui bahwa peran-peran tertentu berinteraksi (misalnya, peran profesor dan mahasiswa), dan bahwa peran-peran biasanya didefinisikan dalam relasi dengan peran-peran yang lain (misalnya, dokter dan pasien, orangtua dan anak). Namun demikian, oleh karena definisi-definisi fungsionalis berkembang pesat bahkan keluar dari fokusnya terhadap fungsi peran dalam organisasi-organisasi formal dan jejaring status, peran-peran dilihat sebagai struktur-struktur yang secara relatif tidak fleksibel, dan sulit untuk dikombinasikan. Multipisitas peran (peran ganda) seringkali dinilai secara negatif oleh karena konsepsi-konsepsi fungsionalis menekankan secara khusus cara individu konform terhadap apa yang diharapkan darinya dengan keutamaan menjalani peran tertentu pada waktu tertentu, melakukan pola-pola perilaku yang ditentukan oleh norma-norma dan aturan-aturan. Peran ganda dipandang sebagai sumber ketegangan peran (role strain, role conflict). Tumpang-tindih dan pergantian antar-peran dalam satu individu dilihat sebagai "penyimpangan" (deviasi), "perkecualian” (eksepsi) dari struktur normal keteraturan sosial. Hal yang luput dari analisis fungsional peran adalah dimensi mental-pengalaman dari kinerja peran, yakni negosiasi-negosiasi peran pada tingkat individual yang memungkinkan pelaku peran untuk berganti antar-peran atau mengombinasikan peran-peran tanpa perlu terjebak dalam konflik peran.

Dalam perspektif interaksionis (sosiologis), peran bersifat adoptif. Artinya, peran tidak dilihat sebagai sesuatu yang telah diresepkan, melainkan sesuatu yang secara konstan dinegosiasikan oleh individu dengan cara-cara yang tentatif dan kreatif. Fokusnya adalah interaksi dan makna dari peranperan. Relasi antara variabel-variabel personal, behavioral, dan sosial dari peran bersifat resiprokal (timbal balik). Setiap orang berdasarkan persepsi dan preferensi subjektifnya berupaya untuk mengkoordinasikan tingkah lakunya dengan orang-orang lain dan untuk mendefinisikan secara bersama hal-hal apa saja yang menyusun sebuah peran. Hal ini senantiasa dilakukan dengan cara interaktif; jadi tidak akan bermakna apabila kita berpikir mengenai satu peran untuk satu orang saja.

Pemain peran (role players) belajar, setidaknya untuk sementara waktu, apa yang diharapkan oleh orang lain melalui pengambilan peran (role taking). Pengambilan peran adalah sebuah proses mengantisipasi respons interaksional dari orang lain. Guna memainkan peran, seseorang harus menempatkan dirinya pada tempat orang lain untuk melihat dunia sebagaimana dilihat orang lain itu, 
menggunakan pengalaman-pengalaman yang pernah dijalani sebelumnya dengan orang lain itu, menggunakan pengetahuan mengenai kategori-kategori sosial orang-orang, menggunakan petunjukpetunjuk simbolis yang tersedia dalam interaksi sebagai pedoman. Pengambilan peran (role taking) memungkinkan pemain peran untuk mengantisipasi konsekuensi dari rencana tindakan dari dirinya maupun dari orang lain, untuk memantau (monitoring) hasil-hasil dari rencana-rencana tersebut, serta untuk memelihara keberlangsungan atau mengarahkan ulang perilaku seseorang berdasarkan pemantauan tersebut.

Oleh karena peran-peran seringkali tidak konsisten dan tidak konkret—namun pada saat yang sama pelaku peran harus mengorganisasikan tingkah laku mereka seolah-olah perannya tegas dan konkret-maka interaksi juga merupakan sebuah penciptaan peran (role making). Sebagai agen yang aktif, individu tidak melulu memainkan peran yang diberikan kepadanya; melainkan, mereka membuat peran-peran itu. Hal ini nyata berangkat dari fakta bahwa seringkali terjadi ketidaksetujuan (disagreement) mengenai bagaimana partisipan dan situasi didefinisikan dalam sebuah interaksi. Misalnya, seorang laki-laki menginginkan untuk memainkan peran tradisional laki-laki dan juga ingin perempuan seorang memainkan peran tradisonal perempuan, namun perempuan itu tidak menghendakinya. Definisi-definisi tersebut seringkali dinegosiasikan oleh para partisipan. Mereka berupaya untuk mempengaruhi pandangan satu sama lain dan mencapai definisi-definisi peran dan situasi yang dapat diterima oleh kedua belah pihak.

\section{Diskusi dan Aplikasi Teori Penilaian Sosial}

Terdapat dua daya tarik utama dari teori penilaian sosial (Deaux, Dane, \& Wrightsman, 1993), yakni: (1) gagasan bahwa sikap-sikap paling baik dipahami sebagai rentang (ranges) daripada posisiposisi spesifik eksak; dan (2) pengakuan tentang jarak optimum antara posisi sikap subjek dan posisi komunikasi persuasif. Namun, terdapat pula kelemahan dari teori penilaian sosial, sehingga teori ini tidak terlalu ekstensif digunakan dalam wilayah-wilayah praktis.

Keterbatasan teori ini adalah: (1) teori ini hampir seluruhnya berurusan dengan variabelvariabel keterlibatan ego (ego involvement) dan kesenjangan/diskrepansi pesan; (2) teori ini tidak terlalu berguna untuk memahami situasi-situasi yang melibatkan lebih dari satu sikap; dan (3) hubungan yang eksak antara keterlibatan ego (ego involvement) dengan ukuran lintang (size of latitudes) masih belum pasti dan memerlukan penyelidikan lebih lanjut.

Implikasi dari pengetahuan teori penilaian sosial adalah kegunaannya sebagai panduan komunikasi persuasif. Pertama, komunikator harus bekerja pada lintang penerimaan atau pun lintang non-komitmen, dan menghindari lintang penolakan. Hal ini karena menurut SJT, perubahan tidak dapat terjadi dalam lintang penolakan. Ketika informasi baru jatuh dalam lintang penolakan, komunikan berhenti mendengarkannya, atau bahkan lebih buruk lagi, menanggapinya secara ekstrim negatif dan argumentatif. Komunikator harus mencari landasan bersama (common ground) bagi dirinya dan komunikan melalui komunikasi dan observasi yang hati-hati terhadap komunikan. Kedua, proses persuasif berlangsung bertahap (gradual) yang melibatkan gerakan-gerakan kecil. Jangan mengharapkan mukjizat pengaruh sosial atau perubahan sikap segera pada diri komunikan. Ketiga, perubahan sikap yang dramatis, luas, dan bertahan harus melibatkan perubahan dalam kelompokkelompok rujukan dengan nilai-nilai yang berbeda (reference groups with differing values).

Aplikasi dari pengetahuan teori penilaian sosial antara lain, sebagai berikut: Pertama, bahwa orang-orang yang dogmatis-fundamentalis-radikal secara kronis memiliki lintang penolakan yang lebar. Oleh karena itu, program deradikalisasi harus dilakukan tahap demi tahap, misalnya melalui diskusi dengan interaksi (baik dengan yang bersangkutan maupun dengan keluarganya); jadi tidak bisa serta-merta menyerang/konfrontasi keyakinan atau pemikiran mereka. Kedua, dalam Psikologi Politik, banyak ditemukan efek asimilasi dan efek kontras (distorsi penilaian sosial). Misalnya, dalam Pemilu 
Amerika Serikat yang lampau. George Bush merupakan seorang Republikan. Hampir seluruh pemilih dari Partai Republik mendukung Bush. Namun, di antara para pemilih Republikan tersebut tentu saja terdapat ragam pemilih yang terentang dari mereka yang liberal sampai dengan mereka yang konservatif. Apabila kita meminta Republikan untuk menilai George Bush dalam dimensi liberalkonservatif, maka kita akan menyaksikan efek asimilasi. Republikan yang liberal akan menilai Bush sebagai lebih liberal, sedangkan Republikan yang konservatif akan menilai Bush sebagai lebih konservatif. Dengan demikian, objek penilaian perseptif yang sama didistorsi untuk menyesuaikan dengan posisi yang telah dipegang oleh pemilih/voter.

Ketiga, menurut teori penilaian sosial (SJT), persuasi yang baik terjadi antara lain bila informasi baru (posisi baru yang ditawarkan oleh orang lain) jatuh dalam lintang penerimaan. Contoh pesan/informasi semacam itu adalah pesan yang bersifat ambigu namun secara umum konsisten dengan sikap awal seseorang. Hal ini banyak diaplikasikan dalam iklan kampanye politik. Pesan-pesan kampanye sengaja dirancang bersifat amat umum ("Meningkatkan Kesejahteraan Rakyat”, "Bersih, Memberantas Korupsi, dan Amanah"), tidak dirinci dalam kerangka waktu dan angka pencapaian tertentu. Hal ini cocok dengan teori komunikasi yang disebut dengan "reflective-projective theory" (Rakhmat, 1993). Pesan kampanye di media massa yang mencerminkan suatu citra yang ambigu membuat orang yang menyimaknya memproyeksikan atau melihat citranya pada penyajian pesan kampanye tersebut. Yang terjadi dalam hal ini adalah efek asimilasi dalam lintang penerimaan.

Keempat, dalam kaitannya dengan keterlibatan ego (ego involvement), kita dapat menyaksikan fenomena sehari-hari dalam dunia sekolah antara orangtua dan guru. Untuk beberapa orangtua, sesegera ketika diskusi antara orangtua dan guru mengarah kepada anak dari orangtua tersebut, maka diskusi tersebut bersifat sangat melibatkan ego. Beberapa orang tua tersebut yang mungkin orangorang yang sangat rasional dapat saja menjadi sangat tidak rasional ketika guru menyebutkan apapun yang bernada kritis tentang anak mereka. Dalam kasus ini, orangtua tersebut memiliki lintang penerimaan yang kecil dan lintang penolakan yang luas, sehingga hampir semua hal yang dibicarakan guru kemungkinan besar jatuh dalam lintang penolakan. Kemungkinan besar pula, bila orangtua mendistorsi setiap hal yang dibicarakan guru, distorsi yang akan terjadi adalah efek kontras, bukan asimilasi. Artinya, efek kontras ini akan membuat sang orangtua memandang komentar-komentar guru sebagai lebih buruk dari kondisi yang sebenarnya.

\section{Diskusi dan Aplikasi Model Deskriptif tentang Respons Sosial}

SRCM (social response context model) memiliki keterbatasan. Pertama, keterbatasan yang jelas adalah bahwa masih tidak semua bentuk respons sosial ada dalam model ini. Misalnya, respons tularan histeris (hysterical contagion) yang ditemukan oleh Levy \& Nail (1993), yakni penyebaran simtom-simtom fisik dari inisiator ke penerima namun tanpa dikenali/diketahui patogennya (virus, bakteri, dan sebagainya), seperti halusinasi digerayangi hantu, yang menyebar dari satu orang ke banyak orang lain. Kedua, model ini tidak membedakan antara upaya-upaya mempengaruhi yang dipersepsikan oleh orang yang dipengaruhi sebagai intensional (disengaja oleh pemberi pengaruh sosial) ataukah tidak intensional. Disarankan dimensi intensional/tak intensional dimasukkan dalam revisi model ini berikutnya.

Di samping keterbatasan, SRCM memiliki kekuatan. Pertama, model ini sangat komprehensif dan berguna dalam mengorganisasikan sejumlah besar temuan-temuan empiris mengenai respons sosial. Kedua, model ini mampu mengintegrasikan riset-riset persuasi dengan pengaruh sosial. Para peneliti tentang persuasi seringkali berfokus pada argumen-argumen detail mengenai persuasi yang tercerai dari setting sosial, sedangkan para peneliti pengaruh sosial seringkali berfokus pada posisiposisi yang lebih sederhana yang diadvokasi oleh beberapa entitas sosial yang penting. Namun, kedua jenis riset ini diakomodasi tanpa kesulitan oleh SRCM. 
Aplikasi SRCM nampak antara lain dalam efek kehadiran orang lain (bystander) dalam perilaku menolong. Penelitian Darley dan Latané yang masyur itu memperlihatkan adanya respons sosial \#11, Inhibitory Independence (Noncontagion). Sebagaimana dijelaskan dalam uraian teoretis, dalam respons sosial ini, sebelum terpapar oleh pengaruh sosial, subjek berada dalam konflik mendekat-menjauh, dan secara privat ingin melibatkan diri dalam perilaku menurut pengaruh sosial, namun secara publik tidak melakukannya. Yang terjadi selanjutnya bukanlah resolusi/penyelesaian konflik tersebut, tetapi subjek tetap terkekang dalam konflik tersebut namun tidak terpengaruh (uninfluenced, independent of) oleh perilaku model yang menjadi sumber pengaruh sosial.

Bila diaplikasikan dalam penelitian efek bystander, konfederat/korban dirancang nampak sedang memerlukan pertolongan. Konfederat (yang sebenarnya teman eksperimenter) ini dikonsepkan sebagai sumber pengaruh sosial (influence source); dan partisipan eksperimen dikonsepkan sebagai orang potensial yang terkena pengaruh sosial (potential influencee). Konfederat berada dalam ruang kecil yang nampak di mata partisipan mengalami perampokan. Para partisipan dimungkinkan menginisiasi (memulai) menampilkan intensi menolongnya dalam rentang waktu enam menit. Darley dan Latané menemukan bahwa seiring dengan bertambahnya jumlah penolong potensial, kemungkinan untuk menolong menurun tajam. Misalnya, ditemukan bahwa ketika para partisipan menyaksikan adanya sejumlah empat orang partisipan lain namun tidak menolong (nonhelping participants), insiden menolong dari para partisipan tersebut hanya 62\%. Dengan demikian, apabila kita mengasumsikan bahwa nonhelping participants tersebut sedikit-banyaknya condong untuk secara privat/pribadi menolong, maka 38\% partisipan lainnya menurut analisis SRCM menampilkan respons sosial berupa "inhibitory independence". Korban yang nyata-nyata memerlukan pertolongan, dalam kondisi ini, tidak cukup kuat untuk memacu (atau untuk melepaskan hambatan/disinhibit) 38\% partisipan tersebut untuk bertindak.

Implikasi dari pengetahuan di atas bagi penyusunan kebijakan publik di Indonesia adalah bahwa adanya fenomena inhibitory independence dalam situasi darurat harus dipertimbangkan oleh pembuat peraturan/kebijakan, yakni guna membuat hukum yang sedapat mungkin mengeliminasi kewajiban hukum dari bystanders yang mencoba menolong dalam suatu kedaruratan. Seringkali bystanders terhambat (inilah mengapa disebut inhibitory) untuk menolong karena antisipasinya terhadap kewajiban hukum yang mungkin ditanggungnya (berurusan dengan polisi yang ruwet, takut kalau-kalau malah dijadikan tersangka), jadi ada konflik mendekat-menjauh yang terpelihara (ingin menolong, namun takut menjadi kesulitan di kemudian waktu); sehingga segawat apapun kondisi korban tidak mampu mempengaruhinya (inilah mengapa disebut independence) untuk menolong. Tujuan dari pembuatan aturan hukum yang demikian adalah untuk meningkatkan kekuatan persuasif dari situasi korban yang terluka/mengalami kemalangan; dengan jalan menghapus sedikitnya satu dari "kekangan” untuk menolong (yakni, rasa takut akan diperkarakan lebih lanjut). Di Barat, aturan yang demikian disebut "Good Samartian laws" yang terinspirasi dari cerita perempuan Samaria yang baik hati (“Orang Samaria”, 2008), sebagai berikut:

\footnotetext{
“Ada seorang pria yang dirampok dan ditinggalkan dalam keadaan sekarat. Kemudian lewatlah seorang imam, seorang pemimpin agama terkemuka Yahudi. Dia mungkin juga takut kalau-kalau dia juga akan dirampok; tetapi mungkin ada alasan yang lebih penting mengapa dia tidak berhenti untuk melihat apakah ia bisa menolong orang yang terluka itu. Bila orang yang sekarat itu mati, dan imam itu menyentuhnya, dia akan disebut "najis". Dia tidak akan diperbolehkan memberikan persembahan di Bait Allah untuk orang-orang. Oleh sebab itulah dia berlalu begitu saja. Orang Lewi adalah orang biasa yang membantu imam. Dia juga berlalu begitu saja. Orang Samaria yang akhirnya berhenti adalah seorang asing, yang tak seorang pun akan menyangka bahwa dia akan menunjukkan simpatinya kepada orang Yahudi. Ternyata, orang Yahudi dan orang Samaria saling membenci. Orang Yahudi memandang rendah orang Samaria dan tidak mau melakukan apa pun untuk mereka. Tetapi dalam cerita ini, Yesus menjadikan orang Samaria sebagai sesama yang baik.”
} 
Bahkan, lebih jauh, di sejumlah wilayah hukum di beberapa negara, bystanders justru sebaliknya dikenai kewajiban hukum apabila tidak menolong korban yang sedang memerlukan pertolongan.

\section{Diskusi dan Aplikasi Teori Peran}

Pendekatan interaksionis (sosiologis) terhadap teori peran sebagaimana diuraikan di atas meskipun cukup memuaskan-masih menyisakan pertanyaan mengenai bagaimana aktor-aktor sosial menegosiasikan tuntutan institusional guna mengadopsi dan mengombinasikan berbagai peran sosial (Lynch, 2007). Pertanyaan ini dijawab secara eksplanatif oleh teori kognitif sosial (social cognitive theory). Permainan peran bukan hanya merupakan respons behavioral (sebagaimana ditekankan oleh pendekatan fungsionalis dan interaksionis tradisional) namun juga merupakan respons kognitif. Sebelumnya, perlu dipahami bahwa terdapat "kognisi dingin" (cold cognition) dengan sifat-sifat: otomatis, implisit, tidak diverbalisasikan, cepat, tidak menggunakan kapasitas kognitif penuh; dan ada kognisi panas (hot cognition) dengan sifat-sifat: disengaja, eksplisit, diverbalisasikan, lambat, dan menggunakan pemrosesan informasi yang dimotivasikan/dikontrol oleh pribadi, menggunakan pemikiran dan atensi penuh.

Kognisi panas lebih fleksibel daripada kognisi dingin. Riset-riset psikologis menunjukkan bahwa orang bergeser kepada kognisi panas ketika: (1) atensinya tertarik pada sebuah masalah; (2) orang tersebut memiliki motivasi kuat karena menonjolnya sebuah isu khusus; (3) skemata gagal untuk menangani secara adekuat stimuli baru (Fiske \& Taylor, dalam Lynch, 2007). Dalam kaitannya dengan peran dan identitas, pengetahuan mengenai kognisi panas dan dingin menunjukkan bahwa ritual-ritual dan stimuli eksternal berinteraksi dengan struktur-struktur mental guna menghasilkan kinerja peran yang berdiferensiasi. Diferensiasi ini dapat membantu menjelaskan kapasitas individu untuk berpartisipasi dalam berbagai orientasi bertindak, bahkan ketika orientasi-orientasi tersebut mengandung unsur-unsur yang tidak konsisten. Diferensiasi ini menentukan kapasitas orang untuk memelihara kerangka-kerangka tindakan yang distingtif, yang dapat diminta untuk menanggapi petunjuk-petunjuk kontekstual, psikologis, atau emosional tertentu; dengan demikian menjelaskan keberlangsungan kinerja peran ganda.

Teori peran di samping dikembangkan oleh Moreno dalam Psikodrama sebagai alat konseling dan psikoterapi, juga dapat diaplikasikan dalam Psikologi Politik. Lok (2009) dari Universitas Cambridge, misalnya, mengembangkan tipologi pemain politik institusional berdasarkan teori peran. Ia menyusun teorinya atas dua dimensi, yakni: (1) disposisi agentik (agentic disposition) yang bersifat makro; dan (2) jarak peran (role distance)—yang bersifat mikro.

Disposisi agentik adalah orientasi agentik predominan dari diri aktor politik dalam hubungannya dengan peran berdasarkan pemahaman diri yang bersifat tergantung konteks (the predominant agentic orientation of the self in relation to the role at hand based on an actor's context dependent self-understanding). Variasi nilai dari disposisi agentik adalah: orientasi masa lalu, orientasi masa sekarang, dan orientasi masa depan.

Jarak peran adalah jarak antara perasaan subjektif individu tentang diri dengan diri yang disiratkan dalam peran yang dimainkan atau diharapkan untuk diperankan (the distance between the individual's subjective sense of self and the self that is implied in the role she is (expected) to perform). Variasi nilai dari jarak peran adalah: (1) jarak peran rendah (dicirikan dengan identifikasi dan komitmen diri dengan peran yang tinggi); dan (2) jarak peran tinggi (dicirikan dengan identifikasi dan komitmen diri dengan peran yang rendah; pemain peran mampu memanipulasi isi perannya, mengkritik peran institusionalnya sendiri). Berdasarkan dimensi-dimensi tersebut, disusun enam tipe ideal pemain politik, sebagaimana Gambar 3. Keenam tipe ideal tersebut dijelaskan sebagai berikut: 
Pertama, konservatisme institusional (institutional conservatism). Menurut tipe ini, aktor politik secara penuh mengidentifikasikan dirinya dengan perannya. Oleh karenanya, ia merasa secara personal berkomitmen dengan perannya yang mengandung reaktivasi pola-pola pikiran dan tindakan masa lalu yang bersifat rutin. Aktor ini disebut prajurit institusional (institutional soldiers). Mereka secara rutin dan otomatis mereproduksi institusi bahkan dalam refleksi terhadap perannya yang bersifat kritis dan berjarak, atau bahkan dalam kontestasi makna atau legitimasi peran. Kedua, sinisme pasif (passive cynicism). Menurut tipe ini, aktor politik kritis, sinis, atau skeptis mengenai peran mereka, namun hanya secara teoretis; karena secara praktis mereka secara rutin mereproduksi strukturstruktur institusi mereka. Hal ini menunjukkan bahwa refleksivitas dan kontestasi yang meningkat dalam diri anggota institusi (seperti partai politik) tidak perlu berarti penurunan stabilitas institusi. Aktor sinisme pasif disebut fetisis praktis (practical fetishist).

Ketiga, resistensi oportunistik (opportunistic resistance). Menurut tipe ini, spesifikasi peran bersifat ambigu. Oleh karenanya, aktor harus berimprovisasi untuk memainkan perannya, kurang memiliki identifikasi dengan perannya, memiliki jarak yang sinis terhadap perannya. Peran itu sendiri dapat memproduksi bentuk-bentuk oportunistik dari perilaku penolakan/resistensi. Aktornya disebut resistor yang cerdik (cunning resistor). Keempat, penilaian yang diimprovisasikan (improvised judgment). Menurut tipe ini, spesifikasi peran bersifat ambigu, namun aktor politik memiliki identifikasi yang tinggi (role distance yang rendah) dengan perannya. Aktor ini ingin sesetia mungkin memainkan perannya, maka ia mengimprovisasikan tindakannya dan bertindak sebagai pengambil keputusan yang bijaksana (prudent decision maker) dengan berjuang untuk memanifestasikan perilaku yang diyakini sang aktor paling tepat bagi situasi yang sedang dihadapi. Penilaian yang diimprovisasikan adalah diperlukan dalam situasi dalam hal mana perilaku-perilaku rutin institusional tidak cukup memadai guna memandu interaksi peran.

Kelima, intervensi berkomitmen (committed intervention). Menurut tipe ini, aktor politik secara kuat mengidentifikasikan diri dengan peran-peran yang berorientasi masa mendatang (futureoriented roles). Mereka mengomitmenkan diri atau bahkan menjadi aktivis yang tekun (zealous activist) dalam institusinya. Aktivis ini secara penuh mengidentifikasikan dirinya dengan perannya dan secara sukses melaksanakan proyek-proyek intervensinya. Identifikasi pribadi dan komitmen dengan peran dalam tipe ini bukan berarti aktor politik tidak mampu secara kritis merefleksikan peran dan legitimasinya (meskipun mereka mungkin tidak menginginkannya). Hanya saja, kemungkinannya kecil bahwa tipe aktor politik ini berefleksi dengan cara-cara yang bersifat sinisme yang permanen dan berjarak. Keenam, intervensi tak berkomitmen (uncommitted intervention). Menurut tipe ini, aktor politik terlibat dalam perannya secara manipulatif. Hal ini disebabkan karena ia memiliki disposisi agentik yang berorientasi masa depan namun pada saat yang sama memiliki tingkat jarak peran yang tinggi. Aktor politik ini mampu memainkan permainan politik perubahan (change politics game), memiliki fleksibilitas peran, dan strategis (skilled strategic). Ia tidak memiliki minat individual yang tetap, serta membiarkan tujuan-tujuan dan upaya-upaya pencapaian mereka bersifat terbuka (open), dan secara strategis memenuhi (ataupun menolak) perubahan-perubahan institusional dengan mempengaruhi kerjasama (kooperasi) dari orang-orang lain.

Aplikasi dari pengetahuan enam tipe peran aktor politik di atas bersifat praktis dalam memahami dinamika stabilitas dan perubahan dalam lapangan institusional. Lapangan yang didominasi oleh prajurit institusional (institutional soldiers) lebih mungkin stabil daripada yang didominasi oleh politisi manipulatif. Konfigurasi interaksi antara prajurit institusional dan politisi manipulatif akan berbeda dengan interaksi antara agen perubahan yang tekun (zealous change agents) dan sinis yang pasif (passive cynics), atau antara pengambil keputusan yang bijaksana (prudent decision makers) dan resistor yang cerdik (cunning resistors). 


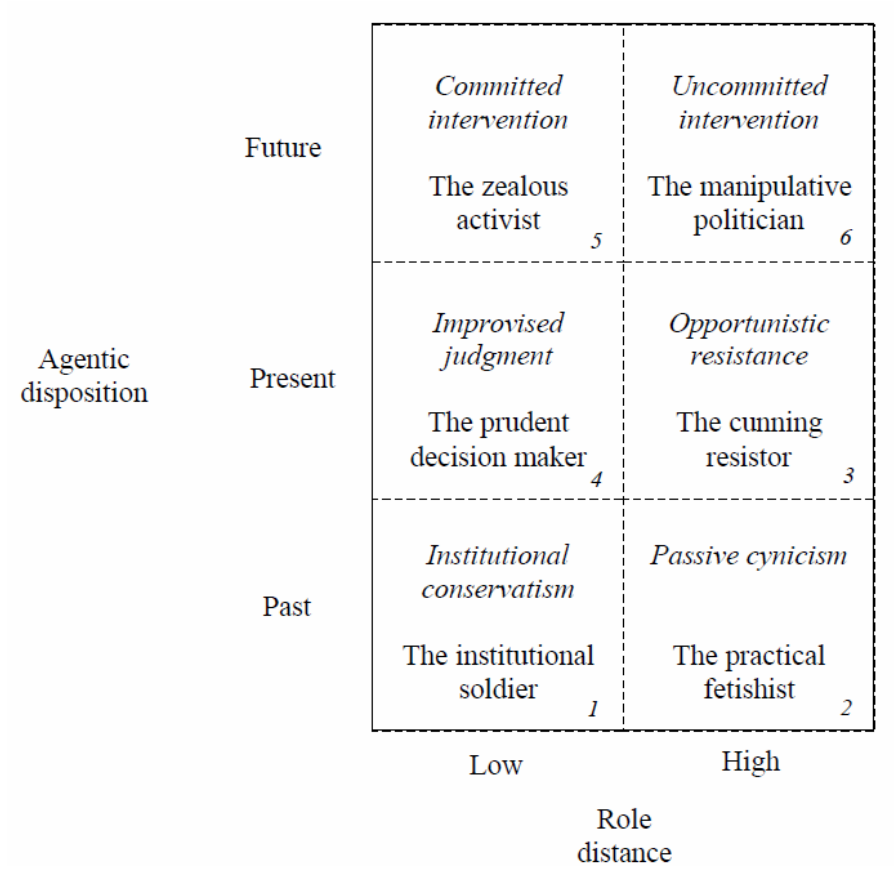

Gambar 5 Enam tipe ideal pemain politik berdasarkan disposisi agentik dan jarak peran Sumber: Lok (2009)

\section{PENUTUP}

Masyarakat Indonesia dikenal sebagai masyarakat yang kolektivistik. Dengan demikian, masih perlu dipertanyakan apakah teori-teori psikologi sosial yang terlampau mengandalkan penjelasan dari dimensi individual (seperti Teori Penilaian Sosial) memang memadai untuk diaplikasikan di Indonesia; ataukah kita justru perlu menekankan perhatian pada teori-teori psikologi sosial yang sungguh-sungguh mempertimbangkan dimensi sosiologis (seperti Teori Peran Interaksionis) untuk memahami gejala-gejala psikologis sosial di Indonesia. Kajian dan/atau penelitian transorientasional lebih lanjut perlu terus menjawab pertanyaan ini.

\section{DAFTAR PUSTAKA}

Alaya, D. B. (2009). Representations, knowledge transmission and social transformations. 10th International conference on social representations (05-08 July 2010, Tunisia). Diunduh pada 1 Juni 2011, dari http://www.10cirs.org/download/theorie en.pdf

Barenbaum, N. B. (2000). How social was personality: The Allports' "connection" of social and personality psychology. Journal of the History of the Behavioral Sciences, 36(4),471-487.

Deaux, K., Dane, F. C., \& Wrightsman, L. S. (1993). Social psychology in the 90's (6th ed.). Pacific Grove, CA: Brooks/Cole. 
Giles, D. (2003). Media psychology. Mahwah, NJ: Lawrence Erlbaum Associates.

Littlejohn, S. W. (2002). Theories of human communication. Belmont, CA: Wadsworth.

Lok, J. (2009). Fetishists, politicians and resistors: Role theory as a lens for understanding institutional actors. Dalam G. T. Solomon (Ed.), Proceedings of the Sixty-Sixth Annual Meeting of the Academy of Management.

Lynch, K. L. (2007). Modeling role enactment: Linking role theory and social cognition. Journal for the Theory of Social Behaviour, 37(4), 379-399.

MacDonald, G., Nail, P. R., \& Levy, D. A. (2004). Expanding the scope of the social response context model. Basic and Applied Social Psychology, 26(1), 77-92.

Orang Samaria yang baik hati. (2008, 21 Februari). Diakses dari http://pepak.sabda.org/pustaka/081736/, pada 30 November 2009.

Rakhmat, J. (1993). Psikologi komunikasi. Bandung: Remaja Rosdakarya.

Sarwono, S. W. (2002). Teori-teori psikologi sosial. Jakarta: Raja Grafindo Persada.

Shaw, M. E., \& Costanzo, P. R. (1970). Theories of social psychology. New York: McGraw-Hill.

Sherif, C., Sherif, M., \& Nebergall, R. (1965). Attitude and attitude change: The social judgmentinvolvement approach. Philadelphia: Saunders.

Sherif, M. A. (1963). Social categorization as a function of latitude of acceptance and series range. Journal of Abnormal and Social Psychology, 67, 148-156.

Social Psychology/Introduction. (2009). Wikipedia Online. Diakses dari http://en.wikibooks.org/wiki/Social_Psychology/Introduction , pada 1 Juni 2011.

Yang, D-J., \& Yang, C-H. (2007). Explanation for rumors as assimilation-contrast theory: Neutralization and immunization. International Colloquium On Business \& Management $19-$ 22 November 2007. Diunduh pada 1 Juni 2011, dari http://icbm.bangkok.googlepages.com/107.Chin.Hua.Yang.PAR.pdf 